\title{
Inclusive Practices: Strengthening Character Through Social Participation of Deaf Students
}

\section{Praktek Inklusif : Penguatan Karakter Melalui Partipasi Sosial Mahasiswa Tunarungu}

\author{
Amka Amka*, Mirnawati Mirnawati \\ Program Studi Pendidikan Khusus, Universitas Lambung Mangkurat,, Banjarmasin, Indonesia
}

This study aims to observe and analyze the practice of social participation of students with hearing impairment in realizing character strengthening in the inclusive campus of Lambung Mangkurat University, Banjarmasin. The research respondents were 31 people in one class, consisting of 5 deaf students and 26 other peer students. Social participation is researched through three key elements, namely: friendship social relations, acceptance of classmates, and student perceptions. This research uses a quantitative approach with a survey method. Data collection techniques using interviews, questionnaires, and documentation. The data analysis technique used descriptive statistics. The results showed the success of strengthening character education through social participation in an inclusive setting for students with hearing impairment with their peers or vice versa.

OPEN ACCESS ISSN 25482254 (online) ISSN 20893833 (print)

Edited by: Rifki Afandi

Reviewed by: Emy Pratiwi

${ }^{*}$ Correspondence: Amka Amka amka.plb@ulm.ac.id

Received: 7 April 2020

Accepted: 14 April 2020

Published: 21 April 2020

Citation:

Amka A and Mirnawati M (2020) Inclusive Practices: Strengthening Character Through Social

Participation of Deaf Students. PEDAGOGIA:Jurnal Pendidikan.

Keywords: Inclusive Education, Character Education, Social Participation, Deaf Deaf

Penelitian ini bertujuan untuk mengamati dan menganalisis praktek partisipasi sosial mahasiswa tunarunggu dalam mewujudkan penguatan karakter di kampus inklusif Universitas Lambung Mangkurat Banjarmasin. Responden penelitian sebanyak 31 orang dalam satu kelas, terdiri dari 5 orang mahasiswa tunarungu dan 26 orang mahasiswa sebaya lainnya. Partisipasi sosial diteliti melalui tiga elemen kunci yaitu: hubungansosial pertemanan, penerimaan teman sekelas, dan persepsi mahasiswa. Penelitian menggunakan pendekatan kuantitatif dengan metode survey. Teknik pengumpulan data menggunakan wawancara, angket, dan dokumentasi. Teknik analisis data menggunakan statistik deskriptif. Hasil penelitian menunjukkan keberhasilan penguatan pendidikan karakter melalui partisipasi sosial dalam setting inklusif bagi mahasiswa tunarunggu dengan teman sebayanya atau sebaliknya.

Keywords: Inclusive Education, Character Education, Social Participation, Deaf Deaf

doi: 10.21070/pedagogia.v9i2 280 


\section{PENDAHULUAN}

\section{Pendidikan Karakter}

Tema pendidikan karakter seakan tidak pernah selesai untuk didiskusikan. Dari waktu ke waktu terus saja menjadi sorotan bila dikaitkan dengan proses dan hasil pendidikan berupa perilaku siswa sehari-hari. Berbagai rumusan terus saja ditawarkan oleh para pakar pendidikan, psikologi, dan ilmu sosial lainnya. Rumusan yang ditawarkan sangat beragam tekanannya, tergantung dari sudut pandang dan latar belakang keilmuan. Namun satu hal yang menjadi kesepakatan bahwa karakter selalu dikaitkan dengan persoalan manusia yang baik dalam berbicara dan bertindak. Pendidikan karakter bertujuan menghasilkan kualitas manusia bernilai baik dan benar, berdimensi universal, tidak sektoral, dapat diterima di setiap tempat dan waktu, yang diwujudkan dalam tindakan bernilai manfaat bagi orang lain dan lingkungan. Jones and Stoodley (1999) dan Williams (2000), berpendapat bahwa pendidikan karakter ditujukan pada pengembangan "kualitas pribadi," atau pengembangan komunitas dalam konteks kehidupan. Dari perspektif kualitas pribadi, pendidikan karakter adalah pengajaran yang bertujuan mengajarkan "mengetahui yang baik, mencintai yang baik, dan melakukan yang baik" Bebeau et al. (1999). Schaps and Lewis (1999) mengonseptualisasikan pendidikan karakter sebagai instruksi yang mencari pengembangan "peduli, berprinsip, dan bertanggung jawab". Enam karakteristik dasar tujuan pendidikan yang sering digambarkan adalah: kebiasaan moral, alasan moral, kebajikan, nilai-nilai, pengambilan keputusan individu, dan tanggung jawab dalam konteks kehidupan. Martinson (2003); Brogan and Brogan (1999); Jones and Stoodley (1999); Lickona (1999)

Pendidikan karakter bukanlah sekedar untuk pengembangan pikiran dan perasaan, tetapi lebih dari itu adalah pendidikan karakter berpusat pada hati, untuk melahirkan kekuatan pikiran positif, kepekaan perasaan, dan kekuatan perilaku baik Azis (2012). Kekuatan karakter adalah dasar dari pengembangan dan pertumbuhan hidup yang optimal. Karakter yang baik bukan hal yang tunggal tetapi jamak, bersifat positif yang ditunjukkan dalam pikiran, perasaan, dan perilaku seseorang. Jika masyarakat benar-benar peduli dengan karakter yang baik di kalangan anak muda, kita harus menilai kekuatan dan memperhatikan bagaimana mereka berkembang. Pendidik dan orang tua sibuk mengukur kemampuan akademik anak dan memantau kemajuan belajar. Kami berharap bahwa suatu hari nanti sekolah juga akan menilai kekuatan karakter siswa dan juga mencatat kemajuan perkembangan mereka, pendidik dan pembuat kebijakan harus memperhatikan kekuatan karakter tertentu Park and Peterson (2009) . Penelitian secara konsisten menunjukkan bahwa kekuatan "hati" seperti cinta dan syukur, kebersamaan, lebih kuat daripada kesejahteraan dan kekuatan pikiran yang bersifat individu, seperti kreativitas, berpikir kritis , dan penghargaan keunggulan Park and Peterson (2008); Park et al. (2004). Kami telah menemukan bahwa prestasi akademik siswa dipengaruhi oleh serangkaian kekuatan karakter. Di antara siswa sekolah menengah, kekuatan karakter dari ketekunan, cinta, syukur, harapan, dan perspektif memprediksi prestasi akademik. Hasil serupa juga ditemukan di kalangan mahasiswa. Belajar terjadi tidak hanya kepada seseorang tetapi di antara mereka, dan kekuatan karakter dapat memfasilitasi proses pembelajaran Park and Peterson (2009).

Kekuatan karakter adalah aspek kepribadian yang dihargai secara moral. Baumrind and Competence and character through life (1998) mencatat, "Dibutuhkan karakter yang baik untuk menghendaki yang baik, dan kompetensi untuk melakukan yang baik". Banyak program pendidikan tinggi dan sosial saat ini fokus pada membantu kaum muda memperoleh keterampilan dan kemampuan akademik seperti berpikir kritis. Ini membantu kaum muda mencapai tujuan hidup mereka, dan tentu saja penting, namun tanpa karakter yang baik, individu mungkin kurang memiliki keinginan untuk melakukan hal yang benar. Kekuatan karakter, ketika dilakukan, tidak hanya mencegah hasil kehidupan yang tidak diinginkan Botvin et al. (1995) tetapi penting untuk mewujudkan kehidupan peribadi yang berkembang sehat dalam hidupnya Colby and Damon (1992); Weissberg and Greenberg (1998). Semakin banyak bukti menunjukkan bahwa kekuatan karakter yang spesifik, misalnya harapan, kebaikan, kecerdasan sosial, kontrol diri, dan pengendali efek negatif dari stres dan trauma, mencegah atau membatasi masalah. Selain itu, kekuatan karakter membantu kaum muda untuk berkembang mencapai keberhasilan pendidikan, kepemimpinan, toleransi dan penilaian keanekaragaman, kemampuan untuk menunda kepuasan, dan kebaikan Park et al. (2004) . Membangun keku- 
atan karakter dipengaruhi oleh pola pengasuhan dan alam. Berbagai pengaruh berkontribusi pada pengembangan karakter seperti keluarga, sekolah, teman sebaya, dan komunitas Steger et al. (2007). Oleh karena itu dalam konteks pendidikan inklusif, upaya membangun partisipasi sosial anak berkebutuhan khusus dan anak sebaya lainya perlu diperhatikan oleh para pendidik dalam menguatkan pendidikan karakter bagi komunitas siswa secara inklusif.

\section{Pendidikan Inklusif}

Pelayanan pendidikan terhadap anak berkebutuhan khusus telah berubah derastis dalam beberapa dekade terakhir. Mendidik anak-anak penyandang kebutuhan khusus telah menjadi bagian penting dari sekolah regular di banyak negara. Perkembangan pelayanan pendidikan anak berkebutuhan khusus digambarkan dengan istilah 'inklusi. Menurut Rafferty et al. (2001), inklusi mengacu pada 'proses mendidik anak-anak penyandang cacat di ruang kelas reguler di sekolah lingkungan mereka. Di Indonesia setiap warga negara berhak mendapatkan pendidikan Dasar (1945). Layanan pendidikan yang setara dan tanpa diskriminasi kepada semua peserta didik adalah praktik pendidikan yang dijadikan kebijakan dalam sistem pendidikan Indonesia (UU No. 20 Tahun 2003). Pemberian hak pendidikan kepada setiap warga neraga adalah upaya mendukung inisiatif menyelenggarakan "Pendidikan Untuk Semua" yang dicanangkan oleh Perserikatan Bangsa-Bangsa dan deklarasi Salamanca (UNESCO, 1994) yang menegaskan bahwa cara terbaik untuk mencapai "Pendidkkan Untuk Semua" adalah melalui praktek inklusif di sekolah regular. Pendidikan inklusif berkaitan dengan upaya mengatasi hambatan yang mencegah partisipasi dan pembelajaran semua anak, terlepas dari ras, jenis kelamin, latar belakang sosial, gender, kecacatan, dan prestasi hasil belajar di sekolah Booth and Ainscow (2002).

Lembaga pendidikan penyelenggara pendidikan inklusi mempunyai daya tarik tersendiri bagi orang tua anak berkebutuhan khusus, data terbaru menunjukkan bahwa semakin banyak orang tua memilih menyekolahkan anaknya yang berkebutuhan khusus di sekolah penyelenggara pendidikan inklusif, sehingga jumlah anak berkebutuhan khusus yang terdaftar di sekolah penyelenggara pendidikan inklusif telah mengalami peningkatan secara substansial dalam beberapa dekade terakhir Ferguson (2008). Komitmen terhadap pendidikan inklusif di seluruh dunia terus meningkat Sharma et al. (2017) . Beberapa hasil penelitian menegaskan bahwa pendidikan inklusif dipandang sebagai upaya kolektif untuk memberi setiap siswa di komunitas sekolahnya berupa hak untuk memiliki Falvey and Givner (2005). Pendidikan inklusif bertolak belakang dengan paradigma pendidikan terpisah yang membagi siswa dan memberikan penerimaan bersyarat berdasarkan pengukuran kemampuan, pendidikan inklusif bertujuan untuk merangkul semua orang dan menjadikan sekolah sebagai tempat bagi semua siswa Tarmansyah (2007). Komitmen ini berarti bahwa sekolah harus memasukkan sistem yang melibatkan sikap positif terhadap inklusi dan serangkaian strategi agar berhasil untuk mengikutsertakan semua siswa. Selain itu, pendidikan inklusif membutuhkan upaya bersama oleh guru, keluarga, siswa dan kepala sekolah untuk merancang kebijakan inklusif, membangun budaya positif dan menerapkan praktik yang meningkatkan tingkat pengajaran dan pembelajaran yang efektif Ainscow (1999). Dengan demikian pendidikan inklusif merupakan filosofi hidup, belajar bersama, bermanfaat bagi semua orang, termasuk mahasiswa penyandang tunarunggu.

Pendidikan inklusif tidak hanya fokus pada hambatan yang dihadapi siswa tetapi juga, seperti Booth and Ainscow (2002) menyasarankan, berfokus pada pengembangan budaya, kebijakan dan praktik dalam sistem dan lembaga pendidikan, agar mereka dapat menanggapi keragaman siswa mereka dan memperlakukan mereka secara setara. Di sekolah inklusif keragaman disambut dan dianggap sebagai sumber pembelajaran dan bukan masalah. Fakta yang paling penting adalah bahwa pendidikan inklusif adalah proses yang berkelanjutan dan bukan tahap yang dapat kita capai pada saat tertentu.Secara umum, pendidikan inklusif adalah masalah yang kompleks dan kontroversial, sebuah topik yang sering menimbulkan perdebatan sengit di antara para pemangku kepentingan yang berbeda. Ainscow et al. (2000) menyatakan bahwa ada ketidakpastian dan kebingungan seputar makna 'pendidikan inklusif' Petrou (2005) .Kehadiran siswa penyandang cacat memberikan kesempatan bagi semua siswa untuk belajar perbedaan dan menunjukkan empati bagi seorang individu terhadap penyandang cacat yang berbeda 
dengan rasa kasihan atau simpati. Siswa dapat belajar tentang perbedaan dan bermanfaat mendukung individu penyandang cacat Shapiro (1994).

\section{Mahasiswa Tunarungu}

Kebijakan pendidikan inklusif di Indonesia telah diberlakukan di perguruan tinggi (Peraturan Menteri Riset dan Teknologi no. 46 tahun 2017) Menteri (2017). Berdasarkan regulasi tersebut Universitas Lambung Mangkurat Banjarmasin menerima berbagai jenis mahasiswa berkebutuhan khusus, termasuk mahasiswa tunarunggu. Tunarungu adalah seseorang yang mengalami kekurangan atau kehilangan kemampuan mendengar baik sebagian atau seluruhnya, karena diakibatkan tidak berfungsinya alat pendengaran sebagian atau seluruh, dan membawa dampak kehidupan secara kompleks Haenuddin (2013). Hambatan pendengaran menyebabkan anak sangat minim mendapatkan input bahasa, sehingga tunarungu mengalami kesulitan dalam berkomunikasi secara verbal. Pada umumnya, komunikasi tunarungu menggunakan bahasa isyarat, hal demikian pada akhirnya membatasi pergaulan tunarungu dengan sesama tunarungu saja Nur'Aeni (2017).

\section{Partisipasi Sosial}

Banyak negara meninggalkan sistem sekolah khusus dan orang tua memilih sekolah regular untuk anak mereka bersekolah Meijer et al. (2006). Walaupun orang tua ini memiliki motif berbeda untuk memilih pengaturan pendidikan reguler untuk anak mereka, mereka memilih sekolah biasa karena kemungkinan anak mereka untuk berpartisipasi secara sosial dalam kelompok sebaya. Orang tua berharap bahwa anaknya dapat partisipasi sosial Scheepstra et al. (1999). Menurut Koster et al. (2010), istilah 'partisipasi sosial' dapat dijelaskan bahwa Partisipasi sosial siswa berkebutuhan khusus dalam pendidikan reguler adalah adanya kontak/interaksi positif antara anak-anak ini dan teman-teman sekelasnya; penerimaan mereka oleh teman sekelas mereka; hubungan sosial/pertemanan antara mereka dan teman sekelas mereka dan persepsi murid bahwa mereka diterima oleh teman sekelas mereka. Meskipun partisipasi sosial menjadi salah satu motif dari orang tua, penelitian telah menunjukkan bahwa di sekolah reguler tidak secara otomatis mengarah pada peningkatan jumlah kontak dan pertemanan dengan teman sebaya de Monchy et al. (2004). Siswa dengan berbagai jenis kecacatan mengalami kesulitan dalam memperoleh posisi sosial yang baik dalam pendidikan reguler. Beberapa penelitian menunjukkan bahwa anak-anak dengan kebutuhan khusus di sekolah biasa kurang diterima oleh teman-teman sebayanya, memiliki lebih sedikit persahabatan dan kurang sering menjadi bagian dari jaringan di kelas Bramston et al. (2002); Kuhne and Wiener (2000); Frostad and Pijl (2007); Yu et al. (2005). Karena hasil ini, tampak jelas bahwa partisipasi sosial layak mendapat perhatian lebih ketika menerapkan pendidikan inklusif. Karena motif utama orang tua dalam memilih sekolah reguler adalah kemungkinan bagi anak mereka untuk berinteraksi secara sosial, dimensi sosial dipandang sebagai aspek penting dalam melaksanakan pendidikan inklusif dengan sukses. Untuk menyelidiki apakah pendidikan inklusif berhasil, kami berpendapat untuk mengukurnya dalam hal hasil sosial siswa.

Sebagian besar orang tua anak berkebutuhan khusus beranggapan bahwa mereka akan mendapatkan keuntungan positif dalam hal akademik jika menyekolahkan anak mereka di sekolah reguler penyelenggara pendidikan inklusif FREDERICKSON et al. (2004). Disisi lain, motif utama orang tua anak berkebutuhan khusus lebih memilih menyekolahkan anaknya di sekolah reguler penyelenggara pendidikan inklusif daripada di sekolah khusus atau di sekolah luar biasa karena orang tua beranggapan bahwa peluang sosial anak berkebutuhan khusus akan meningkat di sekolah inklusi Scheepstra et al. (1999). Orang tua sangat berharap anak mereka yang berkebutuhan khusus dapat membangun hubungan positif dengan teman sebaya di lingkungan sekolah, karena segala hambatan yang dialami anak berkebutuhan khusus berdampak pada kemampuannya dalam membina hubungan sosial yang baik dengan lingkungan sekitarnya. Sebagaimana hasil penelitian menunjukkan bahwa siswa dengan kebutuhan khusus tidak secara otomatis mengarah pada peningkatan persahabatan di antara siswa dengan kebutuhan khusus dan siswa tanpa kebutuhan khusus Buysse et al. (2002); Guralnick et al. (2007) menunjukkan bahwa hampir seperempat dari siswa dengan kebutuhan khusus 
mengalami kesulitan serius membentuk hubungan dengan rekan-rekan mereka. Beberapa penelitian telah menemukan bahwa siswa dengan gangguan spektrum autis dan siswa dengan kelainan perilaku serius sangat sulit untuk membangun hubungan dengan teman sebaya dan berisiko terisolasi di kelas Chamberlain et al. (2007); de Monchy et al. (2004); Harrell et al. (1997).

Beberapa penelitian di atas menunjukkan bahwa anak berkebutuhan khusus di sekolah penyelenggara pendidikan inklusif masih mengalami kesulitan dalam membina hubungan sosial dengan teman sebaya, kecenderungan sosial mereka masih terbatas pada teman sebaya yang juga mengalami kebutuhan khusus. Mereka kekurangan kontak dengan teman sebaya, keterampilan sosial mereka tidak berkembang serta membentuk konsep diri yang negatif Bender and Wall (1994). Konsep diri negatif mengarah ke eksternalisasi misalnya agresi dan internalisasi misalnya kecemasan Durrant et al. (1990). Anak-anak dengan kebutuhan khusus cenderung memegang posisi sosial yang terpisah di ruang kelas dari waktu ke waktu, yang menyiratkan bahwa isolasi adalah fenomena yang cukup stabil. Berdasarkan fenomena-fenomena yang diuraikan di atas, maka penting untuk memantau dan mengevaluasi sosial anak berkebutuhan khusus di lembaga pendidikan penyelenggara pendidikan inklusif mulai dari jenjang sekolah dasar sampai jenjang perguruan tinggi. Mengingat keberhasilan penyelenggaran pendidikan inklusif bagi anak berkebutuhan khusus tidak terbatas pada ketercapaian pemberian layanan akademik semata, namun juga penting untuk mengembangkan hubungan sosial seluruh masyarakat sekolah. Dimensi sosial dipandang sebagai aspek penting dalam melaksanakan pendidikan inklusif dengan sukses Koster et al. (2009).

Kriteria sebenarnya untuk berhasil menerapkan sistem yang lebih inklusif pada akhirnya tergantung pada apa yang terjadi di sekolah dan ruang kelas Ainscow (2007). Keberhasilan penerapan pendidikan inklusif bergantung pada keberadaan sistem pendukung, yang meliputi pelatihan guru, sumber daya untuk sekolah, dukungan sosial, dan partisipasi masyarakat, misalnya mengembangkan hubungan kolaboratif di antara staf dan dengan orang tua, serta hubungan kolaboratif dengan organisasi yang terlibat dalam masyarakat Kantavong (2018) . Permasalahan yang dihadapi dalam mengevaluasi aspek sosial inklusi adalah ambiguitas konsep yang digunakan oleh peneliti. Seperti yang dijelaskan oleh Koster et al. (2010), berbagai konsep diadopsi untuk menggambarkan dimensi sosial inklusi. Tiga konsep payung - yaitu, partisipasi sosial, integrasi sosial dan inklusi sosial - sering digunakan oleh para peneliti. Namun, ada ketidakjelasan tentang maknanya. Oleh karena itu, Koster et al. (2009) merekomendasikan menggunakan konsep "partisipasi sosial". Beberapa peneliti menggambarkan partisipasi sosial sebagai jumlah pertemanan antar siswa Harper et al. (1999); Hunt et al. (1996), sedangkan yang lain menekankan pentingnya interaksi antara siswa atau konsep diri sosial mereka Kamps et al. (1999), atau cenderung untuk membatasi deskripsi partisipasi sosial mereka pada penerimaan teman sebaya terhadap siswa dengan kebutuhan khusus Odom (2000). Analisis literatur mengungkapkan bahwa terdapat empat tema utama untuk mengukur partisipasi sosial yaitu: persepsi diri sosial siswa, penerimaan oleh teman sekelas, pertemanan / hubungan dan kontak / interaksi Koster et al. (2009), selanjutnya diadopsi dalam penelitian ini, namun peneliti hanya memungkinkan untuk fokus pada 3 tema partisipasi sosial yaitu hubungan pertemanan sosial, persepsi diri sosial, dan penerimaan oleh teman sebaya dalam satu kelas belajar.

Penelitian ini mengkaji dan mendeskripsikan partisipasi sosial mahasiswa berkebutuhan khusus tunarunggu di program studi pendidikan khusus (PKh) Fakultas Keguruan dan Ilmu Pendidikan (FKIP) Universitas Lambung Mangkurat (ULM) Banjarmasin Indonesia sebagai perguruan tinggi penyelenggara pendidikan inklusif.

\section{METODE}

Penelitian ini dilakukan dengan menggunakan pendekatan kuantitatif yaitu mengungkap partisipasi sosial mahasiswa berkebutuhan khusus tunarungu Program Studi Pendidikan Khusus Fakultas Keguruan dan Ilmu Pendidikan Universitas Lambung Mangkurat. Metode pengumpulan data menggunakan metode survey. Menurut Sugiyono (2016) bahwa metode survey digunakan untuk mendapatkan data dari tempat tertentu yang alamiah (bukan buatan). Penggunaan 
metode survey akan memudahkan peneliti untuk memperoleh data untuk diolah dengan tujuan memecahkan masalah yang menjadi tujuan akhir suatu penelitian. Tema payung tiga dari empat tema partisipasi sosial yang diajukan Koster et al. (2009) yaitu hubungan pertemanan sosial, persepsi diri sosial, dan penerimaan oleh teman sebaya dalam satu kelas belajar, digunakan dan dikembangkan sebagai instrumen penelitian, dengan 5 opsi: sangat setuju, setuju, ragu-ragu, kurang setuju, dan tidak setuju. Sumber data pada penelitian ini adalah segala bentuk informasi baik berupa ucapan, ataupun tindakan dari responden terkait partispasi sosial mahasiswa berkebutuhan khusus tunarungu sasaran. Responden dalam penelitian ini adalah mahasiswa berkebutuhan khusus tunarungu sebanyak 5 orang, dan teman sekelas 26 orang. Pengumpulan data dilakukan bekerja sama dengan para volunteer, adapun teknik pengumpulan data yang digunakan ini adalah wawancara dan angket (kuesioner) serta dokumentasi.

Teknik analisis data dalam penelitian ini menggunakan statistik deskriptif dengan rumus:

Nilai $=\frac{\text { skor perolehan }}{\text { skor maksimal }} \times 100 \%$

Nilai yang diperoleh kemudian dimaknai sesuai dengan panduan dibawah iniTabel 1 :

[Table 1 about here.]

\section{HASIL DAN PEMBAHASAN}

\section{Penguatan Karakter Dalam Hubungan sosial/pertemanan antara mahasiswa berkebutuhan khusus tunarungu dengan teman sekelas mereka.}

Penguatan pertemanan antara mahasiswa berkebutuhan khusus tunarungu dengan teman sekelas, menunjukkan hasil pada Tabel 2 .

[Table 2 about here.]

Tabel 2 menunjukkan bahwa mahasiwa tunarungu menyatakan hubungan sosial atau pertemanan antara mahasiswa berkebutuhan khusus tunarungu dengan teman sekelas adalah sangat setuju $10 \%$, setuju $60 \%$, ragu-ragu, $8.5 \%$, tidak setuju $21.5 \%$, dan sangat tidak setuju $0 \%$. Penelitian ini menemukan penguatan karakter melalui partisipasi sosial cukup baik yaitu sebesar 70\% $(10 \%+60 \%)$ yang dibuktikan dalam praktek hubungan sosial/pertemanan antara mahasiswa berkebutuhan khusus tunarungu dengan teman sekelas mereka. Penguatan karakter melalui hubungan sosial pertemanan antara mahasiswa berkebutuhan khusus tunarungu dengan teman sekelas mereka dikatakan cukup baik atau kuat, sehingga dapat mengatasi masalah mahasiswa tunarungu yang mengalami kesulitan dalam menjalin pertemanan dan tidak percaya diri dalam berinteraksi. Kondisi hubungan sosial pertemanan menunjukkan kekuatan karakter dalam pertemanan untuk mengantisipasi terjadinya masalah hambatan pendengaran. Hambatan pendengaran pada mahasiswa tunarungu berdampak pada bahasa dan komunikasinya. Mahasiswa tunarungu kesulitan dalam berinteraksi karena kemampuan interaksi sosial membutuhkan kemampuan berbahasa yang baik sementara mahasiswa tunarungu kesulitan dalam berbahasa lisan (verbal), kesulitan komunikasi tersebut berakibat terhambatnya keterampilan sosial dan hubungan sosial yang sesuai Antia et al. (2011). Mahasiswa tunarungu berkomunikasi dengan menggunakan bahasa isyarat sementara teman sekelas mereka tidak semua mengerti dan memahami maksud dari setiap isyarat yang dilakukan tunarungu. Para peneliti dan praktisi secara khusus juga menunjukkan keprihatinan terhadap interaksi sosial anak dengan gangguan pendengaran yang belajar di sekolah inklusi, karena keterbatasan komunikasi dan interaksi teman sebaya Kluwin (2002).

Kondisi demikian pada akhirnya menjadikan interaksi tidak berkesan, tidak menyenangkan, karena tidak adanya koneksi dalam pembicaraan tersebut, sementara syarat terjadinya interaksi sosial yang baik adalah ketika didalamnya lawan bicara bisa saling memahami maksud dari pembicaraan. Everett M. Rogers seorang pakar Sosiologi Pedesaan Amerika yang telah memberi banyak perhatian pada studi riset komunikasi, khususnya dalam hal penyebaran inovasi seperti dikutip oleh Cangara (2006: 19) dalam Bintoro (2011) membuat definisi bahwa 
komunikasi adalah proses di mana suatu ide dialihkan dari sumber kepada satu penerima atau lebih dengan maksud untuk mengubah tingkah laku yang pada gilirannya akan tiba pada saling pengertian yang mendalam. Pengalaman-pengalaman interaksi sosial yang seringkali sulit dan mengecewakan bagi tunarungu seperti kesulitan dalam memahami pembicaraan lawan bicara, keliru dalam mempersepsikan ekspresi dan bahasa tubuh orang lain, begitu pun sebaliknya lawan bicara tidak mampu memahami maksud dari tunarungu. Yull (2004) dalam W.R. (2009) Seperti yang dialami oleh Disca, salah seorang tunarungu yang mengalami masalah sosial, salah satunya karena bersekolah di sekolah reguler/ umum ia dapat mengerti bahasa temannya tetapi temannya tidak dapat mengerti bahasanya.

Kondisi demikian membentuk anak tunarungu menjadi pribadi yang kurang bahkan tidak memiliki rasa percaya diri. Rasa percaya diri adalah satu di antara aspek-aspek kepribadian yang penting dalam kehidupan manusia. Rasa percaya diri sangat membantu manusia dalam perkembangan kepribadiannya. Karena itulah rasa kepercayaan diri sangat dibutuhkan manusia dalam menjalani hidupnya termasuk pada anak tunarungu. Dalam hubungan dengan partisipasi sosia, mahasiswa tunarungu sebagian besar bersikap ragu-ragu atau tidak setuju memi ta bantuan kepada teman sekelasnya atas masalah yang dihadapi. Hal tersebut terjadi kemungkinan disebabkan karena mahasiswa tunarungu terkendala dalam menyampikan masalahnya ke teman sekelas, mahasiswa tunarungu tidak realistis akan kondisi dirinya yang mengalami keterbatasan sehingga mutlak membutuhkan orang lain sebagai makhluk sosial. Bahwa ada hubungan yang signifikan antara percaya diri dengan kemampuan komunikasi anak tunarungu di SDLB-B Karya Mulia II Surabaya. Kepercayaan diri adalah keyakinan untuk melakukan sesuatu pada diri sebagai karakteristik pribadi yang mencakup keyakinan akan kemampuan diri, optimis, objektif, bertanggung jawab, rasional, dan realistis (Gufron \& Rini, 2014) dalam Suryani (2010).

Pada perkembangan sosialnya, umumnya individu tuli memiliki masalah pada penyesuaian sosial. Penyesuaian sosial merupakan kapasitas untuk bereaksi secara efektif atau adekuat terhadap kenyataan yang ada di lingkungannya sehingga individu akan mampu untuk memenuhi tuntutan sosial dengan cara yang dapat diterima dan memuaskan bagi dirinya maupun lingkungannya Nurihsan and Agustin (2000). Wujud dari keberhasilan penyesuaian sosial ini antara lain, kemampuan individu dalam menjalin komunikasi dengan orang lain, menyelaraskan antara tuntutan dirinya dengan tuntutan lingkungan, memenuhi aturan kelompok masyarakat dan mampu menciptakan suatu relasi yang sehat dengan orang lain, mengembangkan persahabatan, berperan aktif dalam kegiatan sosial. Selain itu, menghargai nilai-nilai, hukum-hukum sosial dan tradisi atau dapat dikatakan mampu bertindak sesuai dengan norma yang berlaku dan lain sebagainya.

\section{Penguatan Karakter Melalui Persepsi Mahasiswa Berkebutuhan Khusus Tunarungu Terhadap Penerimaan Teman Sekelas}

Persepsi mahasiswa berkebutuhan khusus tunarungu terhadap penerimaan teman sekelas ditunjukkan pada Tabel 3 .

[Table 3 about here.]

Tabel 3 menunjukkan bahwa mahasiswa tunarungu menyatakan persepsinya terhadap penerimaan teman sekelas mereka adalah sangat setuju $16 \%$, setuju $66 \%$, ragu-ragu, $4 \%$, tidak setuju $14 \%$, dan sangat tidak setuju $0 \%$. Penelitian ini menemukan penguatan karakter melalui partisipasi sosial yang baik atau kuat sebanyak $82 \%(16 \%+66 \%)$, yang dibuktikan dalam pratek dimensi persepsi mahasiswa berkebutuhan khusus tunarungu terhadap penerimaana teman sekelas.Tanggapan mahasiswa berkebutuhan khusus tunarungu terhadap penerimaan teman sekelasnya termasuk dalam kategori karakter baik atau kuat. Mahasiwa tunarungu merasakan adanya sikap yang baik teman sekelas terhadap mereka. Pada umumnya teman sekelas memahami kondisi dan hambatan mahasiswa tunarungu. Mahasiswa tunarungu beranggapan bahwa teman sekelas memperlakukan mereka dengan baik, namun disisi lain beberapa dari mahasiswa tunarungu beranggapan bahwa terdapat teman sekelas yang tidak mau menerima tanggapan dari mahasiswa tunarungu, dan ada teman sekelas yang tidak ingin mengajaknya ke kantin. 
Kondisi demikian tidak lepas dari kondisi beberapa teman sekelas yang kesulitan dalam berkomunikasi dengan mahasiswa tunarungu, bukan tidak ingin mengajak namun mereka bingung bagaimana cara mengajak mahasiswa tunarungu berhubung komunikasi lisan juga sulit dipahami oleh mahasiswa tunarungu sementara mereka tidak bisa berbahasa isyarat.

Empati mempengaruhi apakah individu tersebut akan memberikan maaf atas kesalahan yang dilakukan oleh individu lain ataukah tidak. Menurut Gagan (1983) dalam Silfiasari (2017) empati berarti kemampuan untuk merasakan apa yang dirasakan oleh orang lain. Ketika siswa regular mengerti perasaan dari temannya yang merupakan siswa berkebutuhan khusus, maka akan muncul rasa menghargai. Siswa regular akan memahami bagaimana keadaan dari siswa berkebutuhan khusus yang mempunyai keterbatasan-keterbatasan. Dari sini rasa penghargaan dan rasa empati akan muncul, jadi ketika siswa berkebutuhan khusus melakukan kesalahan maka siswa regular akan memaafkan siswa berkebutuhan khusus. Tidak mengherankan, jika mahasiswa tunarungu beranggapan mengalami kesulitan dalam menjalin berteman dengan teman sebaya. Banyak siswa tunarungu melaporkan bahwa meskipun mereka berpartisipasi dalam kegiatan sosial dengan teman sebaya yang mendengar, namun hubungan mereka bersifat jangka pendek dan santai, mereka merasa aman secara emosional hanya dengan temanteman yang juga tunarungu, meskipun juga terdapat beberapa siswa tunarungu secara emosional aman dengan teman sekelas yang mendengar Stinson (1999). Faktor-faktor yang tampaknya mempengaruhi hubungan sosial yang baik adalah kesempatan untuk berinteraksi dengan teman-teman dengar, dukungan guru untuk interaksi, dan peluang untuk terlibat dengan teman sebaya dalam kegiatan ekstrakurikuler Stinson (1999).

\section{Penguatan Karakter Melalui Penerimaan Teman Sekelas Terhadap Mahasiswa Berkebutuhan Khusus Tunarungu}

Penguatan karakter melalui penerimaan teman sekelas terhadap mahasiswa berkebutuhan tunarungu ditunjukkan padaTabel 4 .

\section{[Table 4 about here.]}

Tabel 4 menunjukkan bahwa sebanyak 23 orlangahasiwa menyatakan penerimaan mereka sebagai teman sekelas terhadap mahasiswa tunarungu sangat setuju $67 \%$, setuju $30 \%$, ragu-ragu, $3 \%$, tidak setuju $0 \%$, dan sangat tidak setuju $0 \%$. Penelitian ini menemukan penguatan karakter melalui partisipasi sosial sebesar $97 \%(67 \%+30 \%)$ yang dibuktikan paktek dalam hal penerimaan teman sekelas terhadap mahasiswa tunarungu.

Penerimaan teman kelas terhadap mahasiswa berkebutuhan khusus tunarungu termasuk dalam kategori penguatan karakter sangat baik. Hal ini dibuktikan melalui teman sekelas dengan menunjukkan pemahaman yang baik terkait kondisi mahasiswa tunarungu. Pemahaman tersebut menjembatani terbentuknya penerimaan yang positif pula. Sebagain besar mahasiswa reguler, teman sekelas tidak pernah menunjukkan rasa iri terhadapa mahasiswa tunarungu yang mendapatkan perhatian dari dosen, ikut membantu mahasiswa tunarungu yang mengalami kesulitan, Dengan senang hati menerima keberadaan mahasiswa tunarungu dalam kelompok belajar, bersedia mendengarkan mahasiswa tunarungu bercerita dengan menggunakan bahasa isyarat maupun oral, tidak memebalas saat mahasiswa tunarungu marah, menganggap mahasiswa tunarungu sebagai teman yang sama dengan teman yang lainnya, serta tidak menghindari mahasiswa tunarungu.

Adanya penerimaan yang baik teman kelas terhadap mahasiswa tunarungu menunjukkan tercapainya salah satu indikator keberhasilan penyelenggaraan pendidikan inklusif di Program Studi Pendidikan Khusus Universitas Lambung Mangkurat. Menurut penelitian Mastropieri and Scruggs (1994) faktor keberhasilan dari sekolah inklusif adalah penerimaan atmosfer yang baik, yang dalam hal ini adalah keberadaan teman sebaya. Penelitian dari Miller \& Miller dalam Hasan and Handayani (2014) menyebutkan bahwa teman dapat memberikan dukungan agar siswa berkebutuhan khusus dapat belajar dengan baik. Penelitian Bond \& Castagnera dalam Hasan and Handayani (2014) menjelaskan bahwa teman sebaya dapat membantu siswa berkebutuhan khusus dalam komunikasi dan penyesuaian diri di sekolah. Ketika siswa berkebutuhan khusus mengalami kesulitan dalam belajar, maka siswa regular akan bersedia membantu 
dengan senang hati. Siswa regular membantu siswa berkebutuhan khusus untuk menyesuaikan diri di sekolah dan berinteraksi dengan semua komponen-komponen yang ada di sekolah. Salah satu contoh adalah ketika siswa berkebutuhan khusus ketinggalan penjelasan dari guru di kelas, maka siswa regular membantu menjelaskan dengan bahasa sehari-hari yang mudah dimengerti oleh siswa berkebutuhan khusus. Siswa regular membantu siswa berkebutuhan khusus belajar sebagai teman kepada teman, memberikan rasa nyaman sehingga siswa berkebutuhan khusus lebih cepat mengerti tentang pembelajaran di kelas ketika dijelaskan oleh teman sebayanya. Tetapi, ketika interaksi yang positif tidak bisa tercapai, maka interaksi negatiflah yang akan muncul dalam suatu pertemanan. Magee and Smith (2013) menyatakan ketika siswa regular mengerti ketidakmampuan dari siswa berkebutuhan khusus dan mengerti pentingnya untuk membantu mereka, maka lingkungan komunikasi yang aman dan lancar akan tercipta antara siswa regular dan siswa berkebutuhan khusus, sehingga akan meminimalisir terjadinya konflik dalam hubungan pertemanan mereka.

\section{KESIMPULAN}

Pendidikan inklusif dengan memasukkan semua anak berkebutuhan khusus di sekolah umum, termasuk kampus Universitas Lambung Mangkurat Banjarmasin, telah memberikan keuntungan positif bagi mahasiswa penyandang tunarungu dan mahasiswa sebaya lainnya. Mereka secara bersama-sama dapat berpartisipasi sosial melalui hubungan pertemanan antara mahasiswa berkebutuhan khusus tunarungu dengan teman sekelas mereka, persepsi mahasiswa berkebutuhan khusus tunarungu terhadap Penerimaan Teman Sekelas, dan penerimaan teman sekelas terhadap mahasiswa berkebutuhan khusus tunarungu. Melalui kegiatan partisipasi sosial pula dapat memfasilitasi pembentukan penguatan karakter. Artikel penelitian ini menunjukkan peran partisipasi sosial dapat memberikan dukungan positif dalam penguatan pendidikan karakter. Selan itu penelitian ini dapat menegaskan adanya dukungan kuat antara partisipasi sosial anak tunarunggu dengan pendidikan karakter dalam setting praktik inklusif. Dengan demikian keberhasilan pendidikan inklusif tidak lagi dilihat hanya pada aspek akademik, tetapi penting pula membangun kemampuan dan keterampilan mahasiswa berkebutuhan khusus dalam melakukan peran partisipasi sosial antara sesama mahasiswa.

\section{REFERENCES}

Ainscow, M. (1999). Understanding the Development of Inclusive Schools (London: Routledge Falmer).

Ainscow, M. (2007). From Special Education to Effective Schools for all: A Review of Progress so Far. In The SAGE Handbook of Special Education, ed. L. Florian (SAGE), 146-59.

Ainscow, M., Farrell, P., and Tweddle, D. (2000). Developing policies for inclusive education: a study of the role of local education authorities. International Journal of Inclusive Education 4, 211-229. doi: 10.1080/13603110050059150.

Antia, S. D., Jones, P., Luckner, J., Kreimeyer, K. H., and Reed, S. (2011). Social Outcomes of Students Who are Deaf and Hard of Hearing in General Education Classrooms. Exceptional Children 77, 489-504. doi: 10.1177/ 001440291107700407.

Azis, A. A. (2012). Hati Pusat Pendidikan Karakter (Melahirkan Bangsa Berakhlak Mulia) (Klaten: CEMPAKA PUTIH).

Baumrind, D. and Competence and character through life (1998). Reflections on Character and Competence (Chicago: The University of Chicago Press), 1-28.

Bebeau, M. J., Rest, J. R., and Narvaez, D. (1999). Beyond the Promise: A Perspective on Research in Moral Education. Educational Researcher 28, 18-26. doi: 10.3102/ 0013189x028004018.

Bender, W. N. and Wall, M. E. (1994). Social-Emotional Development of Students with Learning Disabilities. Learning Disability Quarterly 17, 323-323. doi: 10.2307/
1511128.

Bintoro, T. (2011). KEMAMPUAN KOMUNIKASI ANAK TUNARUNGU. Perspektif Ilmu Pendidikan 23, 12-40. doi: 10.21009/pip.231.2.

Booth, A. and Ainscow, M. (2002). The Index for Inclusion (United Kingdom: Centre for Studies on Inclusive Education).

Botvin, G. J., Baker, E., Dusenbury, L., Botvin, E. M., and Diaz, T. (1995). Long-term follow-up results of a randomized drug abuse prevention trial in a white middle-class population. Journal of the American Medical Association 273, 1106-1112. doi: 10.1001/jama.1995.03520380042033.

Bramston, P., Bruggerman, K., and Pretty, G. (2002). Community Perspectives and Subjective Quality of Life. International Journal of Disability, Development and Education 49, 385-397. doi: 10.1080/1034912022000028358.

Brogan, B. R. and Brogan, W. A. (1999). The Formation of Character: A Necessary Goal for Success in Education. The Educational Forum 63, 348-355. doi: 10.1080/ 00131729908984443.

Buysse, V., Goldman, B. D., and Skinner, M. L. (2002). Setting Effects on Friendship Formation among Young Children with and without Disabilities. Exceptional Children 68, 503-517. doi: 10.1177/001440290206800406.

Chamberlain, B., Kasari, C., and Rotheram-Fuller, E. (2007). Involvement or Isolation? The Social Networks of Children with Autism in Regular Classrooms. Journal of Autism and Developmental Disorders 37, 230-242. doi: 10.1007/ s10803-006-0164-4.

Colby, A. and Damon, W. (1992). SOME DO CARE 
CONTEMPORARY LIVES OF MORAL COMMITMENT (New York: Free Press).

Dasar, U.-U. (1945). Undang-undang Dasar 1945.

de Monchy, M., Pijl, S. J., and Zandberg, T. (2004). Discrepancies in judging social inclusion and bullying of pupils with behaviour problems. European Journal of Special Needs Education 19, 317-330. doi: 10.1080/ 0885625042000262488.

Durrant, J. E., Cunningham, C. E., and Voelker, S. (1990). Academic, social, and general self-concepts of behavioral subgroups of learning disabled children. Journal of Educational Psychology 82, 657-663. doi: 10.1037/0022-0663.82. 4.657.

Falvey, M. A. and Givner, C. C. (2005). What is an Inclusive School?" In Creating an Inclusive School (Alexandria, VA: Association for Supervision and Curriculum Development), 1-12.

Ferguson, D. L. (2008). International trends in inclusive education: The continuing challenge to teach each one and everyone. European Journal of Special Needs Education 23, 109-129. doi: https://doi.org/10.1080/ 08856250801946236.

FREDERICKSON, N., DUNSMUIR, S., LANG, J., and MONSEN, J. J. (2004). Mainstream- special school inclusion partnerships: pupil, parent and teacher perspectives. International Journal of Inclusive Education 8, 37-57. doi: $10.1080 / 1360311032000159456$.

Frostad, P. and Pijl, S. J. (2007). Does being friendly help in making friends? The relation between the social position and social skills of pupils with special needs in mainstream education. European Journal of Special Needs Education 22, 15-30. doi: 10.1080/08856250601082224.

Guralnick, M. J., Neville, B., Hammond, M. A., and Connor, R. T. (2007). The friendships of young children with developmental delays: A longitudinal analysis. Journal of Applied Developmental Psychology 28, 64-79. doi: 10.1016/j.appdev.2006.10.004.

Haenuddin (2013). Pendidikan Anak Berkebutuhan Khusus Tunarungu (Jakarta Timur: PT Luxima Metro Media).

Harper, G. F., Maheady, L., Mallette, B., and Karnes, M. (1999). Peer Tutoring and the Minority Child With Disabilities. Preventing School Failure: Alternative Education for Children and Youth 43, 45-51. doi: 10.1080/ 10459889909603301.

Harrell, L. G., Kamps, D., and Kravits, T. (1997). The Effects of Peer Networks on Social-Communicative Behaviors for Students with Autism. Focus on Autism and Other Developmental Disabilities 12, 241-256. doi: 10.1177/ 108835769701200406

Hasan, S. A. and Handayani, M. M. (2014). Hubungan Antara Dukungan Sosial Teman Sebaya dengan Penyesuaian Diri Siswa Tunarungu di Sekolah Inklusi. Jurnal Psikologi Pendidikan dan Perkembangan 3, 128-135.

Hunt, P., Alwell, M., Farron-Davis, F., and Goetz, L. (1996) Creating Socially Supportive Environments for Fully Included Students who Experience Multiple Disabilities. Journal of the Association for Persons with Severe Handicaps 21, 53-71. doi: 10.1177/154079699602100201.

Jones, S. C. and Stoodley, J. (1999). Community of Caring: A Character Education Program Designed To Integrate Values into a School Community. NASSP Bulletin 83, 46-51. doi: 10.1177/019263659908360907.

Kamps, D. M., Dugan, E., Potucek, J., and Collins, A. (1999). Effects of cross-age peer tutoring networks among students with autism and general education students. Journal of Behavioral Education 9, 97-115.

Kantavong, P. (2018). Understanding inclusive education practices in schools under local government jurisdiction: a study of Khon Kaen Municipality in Thailand. International Journal of Inclusive Education 22, 767-786. doi: 10.1080/13603116.2017.1412509.

Kluwin, T. N. (2002). Social Processes and Outcomes of InSchool Contact Between Deaf and Hearing Peers. Jour- nal of Deaf Studies and Deaf Education 7, 200-213. doi: 10.1093/deafed/7.3.200.

Koster, M., Nakken, H., Pijl, S. J., and van Houten, E. (2009). Being part of the peer group: a literature study focusing on the social dimension of inclusion in education. International Journal of Inclusive Education 13, 117-140. doi: 10.1080/13603110701284680.

Koster, M., Pijl, S. J., Nakken, H., and Houten, E. V. (2010). Social Participation of Students with Special Needs in Regular Primary Education in the Netherlands. International Journal of Disability, Development and Education 57, 5975. doi: 10.1080/10349120903537905.

Kuhne, M. and Wiener, J. (2000). Stability of Social Status of Children with and without Learning Disabilities. Learning Disability Quarterly 23, 64-64. doi: 10.2307/1511100.

Lickona, T. (1999). Character Education: Seven Crucial Issues. Action in Teacher Education 20, 77-84. doi: 10.1080/01626620.1999.10462937.

Magee, J. C. and Smith, P. K. (2013). The Social Distance Theory of Power. doi: 10.1177/1088868312472732. https: //dx.doi.org/10.1177/1088868312472732.

Martinson, D. L. (2003). High School Students and Character Education It All Starts at Wendy's. doi: 10. 1080/00098650309601222. https://dx.doi.org/10.1080/ 00098650309601222.

Mastropieri, M. A. and Scruggs, T. E. (1994). Text versus hands-on science curriculum: Implications for students with disabilities. Remedial and Special Education 15, 7285. doi: https://doi.org/10.1177/074193259401500203.

Meijer, C. J., Soriano, V., and Watkins, A. (2006). Special Needs Education in Europe. Europe 2.

Menteri, R. P. (2017). Teknologi, dan Pendidikan Tinggi Republik Indonesia Nomor 46 Tahun 2017 Tentang Pendidikan Khusus dan Pendidikan Layanan Khusus di Perguruan Tinggi.

Nur'Aeni (2017). Psikologi Pendidikan Anak Berkebutuhan Khusus (Purwokerto: UMP Press).

Nurihsan, A. J. and Agustin, M. (2000). Dinamika Perkembangan Anak dan Remaja Tinjauan Psikologi, Pendidikan dan bimbingan. vol. 20 (Jakarta: PT. Refika Aditama), 2027.

Odom, S. L. (2000). Preschool inclusion: what we know and where we go from here. Topics in Early Childhood Special Education 20, 20-27. doi: 10.1177/027112140002000104.

Park, N. and Peterson, C. (2008). Positive Psychology and Character Strengths:Application to Strengths-Based School Counseling. Professional School Counseling 12, 8592. doi: 10.5330/psc.n.2010-12.85.

Park, N. and Peterson, C. (2009). Character Strengths: Research and Practice. Journal of College and Character 10. doi: 10.2202/1940-1639.1042.

Park, N., Peterson, C., and Seligman, M. E. P. (2004). Strengths of Character and Well-Being. Journal of Social and Clinical Psychology 23, 603-619. doi: 10.1521/jscp.23. 5.603.50748.

Petrou, A. (2005). Inclusive Education: From the Margin to Inclusion (Kyproepeia: Limassol).

Rafferty, Y., Boettcher, C., and Griffin, K. W. (2001). Benefits and Risks of Reverse Inclusion for Preschoolers With and Without Disabilities: Parents' Perspectives. Journal of Early Intervention 24, 266-286. doi: 10.1177/ 105381510102400403.

Schaps, E. and Lewis, C. (1999). Perils on an essential journey: Building school community. Phi Delta Kappan 81, 215-218.

Scheepstra, A. J. M., Nakken, H., and Pijl, S. J. (1999). Contacts with classmates: the social position of pupils with Down's syndrome in Dutch mainstream education. European Journal of Special Needs Education 14, 212-220. doi: 10.1080/0885625990140303.

Shapiro, J. P. (1994). No pity: People with disabilities forging a new civil rights movement (New York: Random House), $1-400$. 
Sharma, U., Forlin, C., Marella, M., and Jitoko, F. (2017). Using indicators as a catalyst for inclusive education in the Pacific Islands. International Journal of Inclusive Education 21, 730-746. doi: 10.1080/13603116.2016.1251979.

Silfiasari (2017). Empati Dan Pemaafan Dalam Hubungan Pertemanan Siswa Regular Kepada Siswa Berkebutuhan Khusus (ABK) Di Sekolah Inklusif. Jurnal Ilmiah Psikologi Terapan: JIPT 5, 2301-8267. doi: https://doi.org/ 10.22219/jipt.v5i1.3886.

Steger, M. F., Hicks, B. M., Kashdan, T. B., Krueger, R. F., and Bouchard, T. J. (2007). Genetic and environmental influences on the positive traits of the values in action classification, and biometric covariance with normal personality. Journal of Research in Personality 41, 524-539. doi: 10.1016/j.jrp.2006.06.002.

Stinson, M. (1999). Considerations in educating deaf and hard-of-hearing students in inclusive settings. Journal of Deaf Studies and Deaf Education 4, 163-175. doi: 10.1093/deafed/4.3.163.

Sugiyono (2016). Metode Penelitian Pendidikan Pendekatan Kuantitatif, Kualitatif, dan R\&D. (Bandung: Alfabeta).

Suryani, S. F. (2010). Inferioritas dan kepercayaan Diri Pada Penyandang Tuna Rungu. Falkutas Pskologi, 1-5.

Tarmansyah (2007). Inklusi Pendidikan Untuk Semua (Jakarta: Depdiknas)

Weissberg, R. P. and Greenberg, M. T. (1998). Schoo and community competence-enhancement and prevention programs. Journal of Mental Health 7, 479-492.
Williams, M. M. (2000). Models of character education: Perspectives and developmental issues. Journal of Humanistic Counseling, Education and Development 81, 32-40. doi: https://doi.org/10.1002/j.2164-490X.2000.tb00091.x.

W.R., M. S. (2009). Penyesuaian Diri Individu Tunarungu Dalam Melanjutkan Pendidikan di Sekolah Reguler. https://repository.usd.ac.id/28112/2/019114086_Full\% 5B1\%5D.pdf.

Yu, G., Zhang, Y., and Yan, R. (2005). Loneliness, peer acceptance, and family functioning of Chinese children with learning disabilities. Psychology in the Schools 42, 325-356.

Conflict of Interest Statement: The authors declare that the research was conducted in the absence of any commercial or financial relationships that could be construed as a potential conflict of interest.

Copyright (c) 2020 Amka and Mirnawati. This is an open-access article distributed under the terms of the Creative Commons Attribution License (CC BY). The use, distribution or reproduction in other forums is permitted, provided the original author(s) and the copyright owner(s) are credited and that the original publication in this journal is cited, in accordance with accepted academic practice. No use, distribution or reproduction is permitted which does not comply with these terms. 


\section{LIST OF TABLES}

1 Kriteria penilaian penguatan karakter melalui partisipasi sosial mahasiswa tunarungu . . . . . . . . . . . . . . . . . . . . 255

2 Penguatan Karakter Dalam PartisipasiSosial MahasiswaTunarungu di Universitas Lambung Mangkurat . . . . . . . . . . . . . . . . . . . . . . 256

3 Penguatan Karakter Melalui Persepsi mahasiswa tunarungudi Universitas Lambung Mangkurat . . . . . . . . . . . . . . . . . . . . . . 257

4 Penerimaan Teman Sekelas Terhadap MahasiswaBerkebutuhan Khusus Tunarungu di UniversitasLambung Mangkurat . . . . . . . . . . . . . . 258 
TABLE 1 | Kriteria penilaian penguatan karakter melalui partisipasi sosial mahasiswa tunarungu

\begin{tabular}{ll}
\hline Persentase & Kriteria \\
$91 \%-100 \%$ & Sangat baik \\
$76 \%-90 \%$ & Baik \\
$61 \%-75 \%$ & Cukup \\
$51 \%-60 \%$ & Sedang \\
$\leq 50 \%$ & Kurang \\
\hline
\end{tabular}


TABLE 2 | Penguatan Karakter Dalam PartisipasiSosial MahasiswaTunarungu di Universitas Lambung Mangkurat

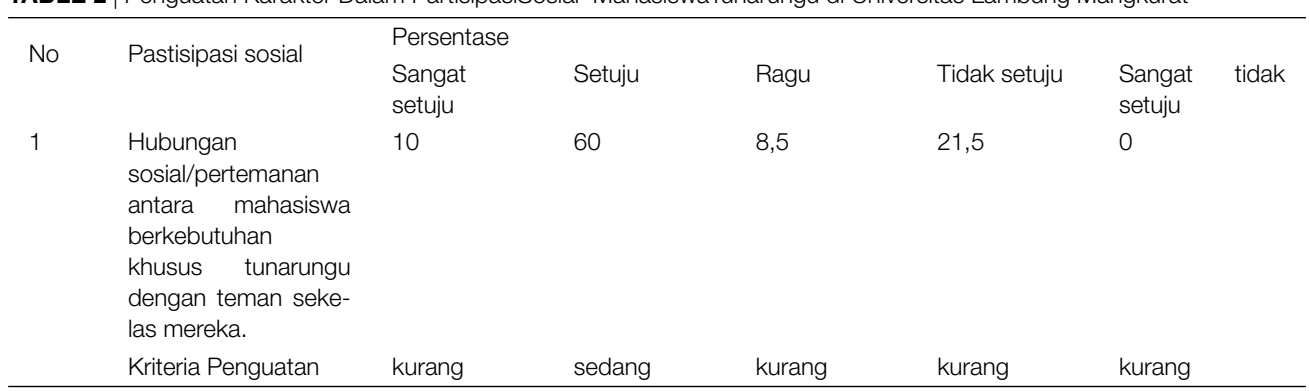


TABLE 3 | Penguatan Karakter Melalui Persepsi mahasiswa tunarungudi Universitas Lambung Mangkurat

\begin{tabular}{|c|c|c|c|c|c|c|}
\hline \multirow{2}{*}{ No } & \multirow{2}{*}{ Pastisipasi sosial } & \multicolumn{5}{|l|}{ Persentase } \\
\hline & & $\begin{array}{l}\text { Sangat } \\
\text { setuju }\end{array}$ & Setuju & Ragu & Tidak setuju & $\begin{array}{l}\text { Sangat } \\
\text { setuju }\end{array}$ \\
\hline \multirow[t]{2}{*}{1} & $\begin{array}{l}\text { Persepsi mahasiswa } \\
\text { berkebutuhan khusus } \\
\text { tunarungu terhadap } \\
\text { penerimaan teman } \\
\text { sekelas mereka }\end{array}$ & 16 & 66 & 4 & 14 & 0 \\
\hline & Kriteria Penguatan & kurang & cukup & kurang & kurang & kurang \\
\hline
\end{tabular}


TABLE 4 | Penerimaan Teman Sekelas Terhadap MahasiswaBerkebutuhan Khusus Tunarungu di UniversitasLambung Mangkurat

\begin{tabular}{|c|c|c|c|c|c|c|c|}
\hline \multirow{2}{*}{ No } & \multirow{2}{*}{ Pastisipasi sosial } & \multicolumn{6}{|c|}{ Persentase } \\
\hline & & $\begin{array}{l}\text { Sangat } \\
\text { setuju }\end{array}$ & Setuju & Ragu & Tidak setuju & $\begin{array}{l}\text { Sangat } \\
\text { setuju }\end{array}$ & tidak \\
\hline \multirow[t]{2}{*}{1} & $\begin{array}{l}\text { Penerimaan teman } \\
\text { kelas terhadap } \\
\text { mahasiswa berke- } \\
\text { butuhan khusus } \\
\text { tunarungu. }\end{array}$ & 67 & 30 & 3 & 0 & 0 & \\
\hline & Kriteria Penguatan & cukup & kurang & kurang & kurang & kurang & \\
\hline
\end{tabular}

